\title{
Settlement and recruitment of the fiddler crabs Uca pugnax and $U$. pugilator in a North Carolina, USA, salt marsh
}

\author{
Nancy J. O'Connor* \\ Department of Marine, Earth and Atmospheric Sciences, North Carolina State University, Raleigh, North Carolina 27695-8208, USA
}

\begin{abstract}
Where larvae settle often is critical for determining the distribution and abundance patterns of later stages of sessile and sedentary marine invertebrates. However, selection of adult habitat by larvae at settlement might be less crucial for invertebrates that have motile benthic stages and have the option of further habitat selection after settlement. If movement after settlement is important in determining spatial patterns of later stages of motile invertebrates, then the distribution and abundance patterns of settling larvae will differ from those of older conspecifics. I tested this hypothesis by documenting the distribution and abundance patterns of settling larvae, juveniles, and adults of the fiddler crabs Uca pugilator and U. pugnax along an intertidal gradient in a North Carolina, USA, salt marsh. Benthic distribution and abundance patterns of conspecific settlers (megalopae and newly-metamorphosed crabs), juveniles, and adult crabs were very similar, but the 2 species generally were spatially separated in the marsh even at the earliest life stage. $U$. pugilator occupied the edge of the marsh next to a tidal creek, whereas $U$. pugnax was most abundant at higher marsh elevations. Because larvae settled in areas with older conspecifics, and the distribution and abundance patterns established at settlement were maintained throughout benthic life, post-settlement movement along a vertical gradient is not important in establishing where adults of these motile benthic species live.
\end{abstract}

\section{INTRODUCTION}

The distribution and abundance patterns of sessile or sedentary marine invertebrates are established by active habitat selection or passive deposition of larvae at the time of settlement, or through juvenile or adult. mortality after settlement (Keough \& Downes 1982). Most research on the importance of settlement and recruitment patterns in determining spatial patterns of adult marine invertebrates has focused on species with sessile or sedentary, rather than motile, adults (reviewed in Crisp 1984, Hadfield 1986). For animals that move little, if at all, after settlement and metamorphosis, where larvae settle largely determines where adults live. In contrast, motile animals have the option of movement and habitat selection after settlement. Therefore, one might expect that the location of larval

\footnotetext{
- Present address: South Carolina Marine Resources Research Institute, 217 Fort Johnson Road, PO Box 12559, Charleston, South Carolina 29422-2559, USA
}

settlement and metamorphosis would be less important in determining spatial patterns of adult stages, especially if juvenile survival and/or growth is greater outside of the adult habitat. For example, juveniles might seek different habitats from adults because the habitats provide better refuges from predation, including cannibalism, access to juvenile foods, or escape from competition with adults (Branch 1984, Werner \& Gilliam 1984, Reaka 1987). On the other hand, movement to the adult habitat after settlement could be disadvantageous if that habitat is rare or patchy, if there is an increased risk of mortality during movement between habitats, or if additional energetic costs are incurred.

In this study I examined how closely the distribution and abundance patterns of settling animals (larvae and newly-metamorphosed juveniles) corresponded to those of older juveniles and adults in the motile, salt-marsh-dwelling fiddler crabs Uca pugilator and $U$. pugnax. The objective was to determine whether adult distributions were affected by post-settlement 
movement of juveniles. Both species are abundant inhabitants of high-salinity marshes along the midAtlantic United States coast (Crane 1975, Montague 1980). Adults are usually spatially separated according to sediment grain size, which tends to vary along an intertidal gradient: $U$. pugilator lives in sandy substrates whereas $U$. pugnax inhabits muddier sediments (Teal 1958, Crane 1975). Their life cycle includes development and dispersal of larvae away from adult habitats to primary estuaries and nearshore coastal habitats (Christy \& Stancyk 1982, Lambert \& Epifanio 1982, Epifanio et al. 1988), followed by reinvasion of shallow estuarine habitats (Christy 1982, Epifanio et al. 1988). Little is known about the transition to benthic existence, including where larvae settle and factors influencing recruitment success.

Adult fiddler crabs can move rapidly over relatively long distances (up to tens of meters during one low tide period; Montague 1980) without a large expenditure of energy (Full \& Herreid 1984). Individuals of Uca pugilator often aggregate into droves that move from high intertidal to low intertidal regions to feed at low tide (Crane 1975). Juvenile crabs also are capable of significant movement. Larvae might be expected to settle in areas maximally suited to their growth and survival, with subsequent movement of juveniles to adult habitats.

Juvenile fiddler crabs are morphologically similar to adults, but certain differences in anatomy and behavior might favor their use of different habitats. Juveniles are considerably smaller than adults, and the relative influence of biological and physical processes on growth and survival of crabs could be related to their size. For example, the feeding biology of adults and juveniles might differ and this could influence the site of larval settlement. Larvae might settle in muddier areas of a marsh because the organic content of sediments (presumably representing potential food for juveniles of both of these deposit-feeding crabs) is higher in muddy than sandy sediments (Levinton 1982). Until reaching the fifth to sixth crab instar several weeks after metamorphosis, juvenile Uca pugilator do not develop the specialized mouthpart structures, commonly found in adults (Crane 1975), that scrape organic material from sand particles (O'Connor 1990a). Thus, they might feed more efficiently on muddy substrata during the early instars. Adult fiddler crabs cannibalize larvae and newly-metamorphosed crabs in the laboratory (O'Connor 1990b), so by settling outside of adult habitats larvae might avoid predation by adults. Because larval and young juvenile $U$. pugilator and $U$. pugnax are morphologically and behaviorally similar and seem likely to experience similar selection pressures, both species might be expected to settle in similar habitats, followed by movement at a later stage to areas occupied by older conspecifics. Juvenile crabs do not dig burrows until the third to fifth crab instar (Hermkind 1968), and would be especially vulnerable to predation by fish or shrimp that occupy marsh habitats during high tide (Kneib \& Stiven 1978, Hettler 1989). Therefore, larvae of both species might settle in areas higher in the intertidal zone where exposure of juvenile crabs to aquatic predators presumably would be less than in the lower intertidal zone, where immersion occurs for a larger proportion of the day.

Because these differences between juvenile and adult stages potentially favor larval settlement outside of adult fiddler crab habitats, I hypothesized that the site of larval settlement is unrelated to spatial patterns of conspecifc adults. Consequently, distribution and abundance patterns of settling animals should be different from those of older conspecifics, and movement to adult habitats would occur after settlement. Alternatively, if settling in the adult habitat were critical for future survival, then the distribution and abundance patterns established at settlement would be similar to those of adults.

I documented the benthic distribution and abundance of newly-settled, juvenile, and adult crabs of the 2 species along an intertidal gradient in a salt marsh. 'Settlers' were defined as megalopae (the terminal larval stage) and newly-metamorphosed crabs (the first crab instar) present on the marsh surface. 'Juveniles' included all crabs (except the first instar) up to $5 \mathrm{~mm}$ carapace width, and 'adults' comprised crabs $10 \mathrm{~mm}$ or more in carapace width, the size at which fiddler crabs are sexually mature (Colby \& Fonseca 1984). Juvenile crabs were examined to assess whether post-settlement movement, if present, occurred relatively soon after settlement (distributions of juveniles different from settlers) or nearer to the adult stage (distributions of juveniles similar to settlers but different from adults).

\section{METHODS}

Study site. Benthic sampling was conducted near the head of a tidal creek in a marsh in the mouth of the Newport River near Beaufort, North Carolina $\left(34^{\circ} 43.5^{\prime} \mathrm{N}, 76^{\circ} 40.5^{\prime} \mathrm{W}\right.$ ) (Fig. 1) in 1986, 1987 and 1988. This marsh is subject to a mean tidal amplitude of $0.91 \mathrm{~m}$ and an annual salinity range of 27 to $37 \mathrm{ppt}$ (Stiven \& Kuenzler 1979); during this study, tidal creek water ranged in salinity from 30 to $36.5 \mathrm{ppt}$ and temperature from 24.5 to $32.5^{\circ} \mathrm{C}$. The marsh surface receives tidal inundation during all phases of the lunar cycle (pers. obs.). In June 1987, the average percentage of silt-and clay-sized particles increased from 40.6 to $86.0 \%$, and the average organic content of the sedi- 


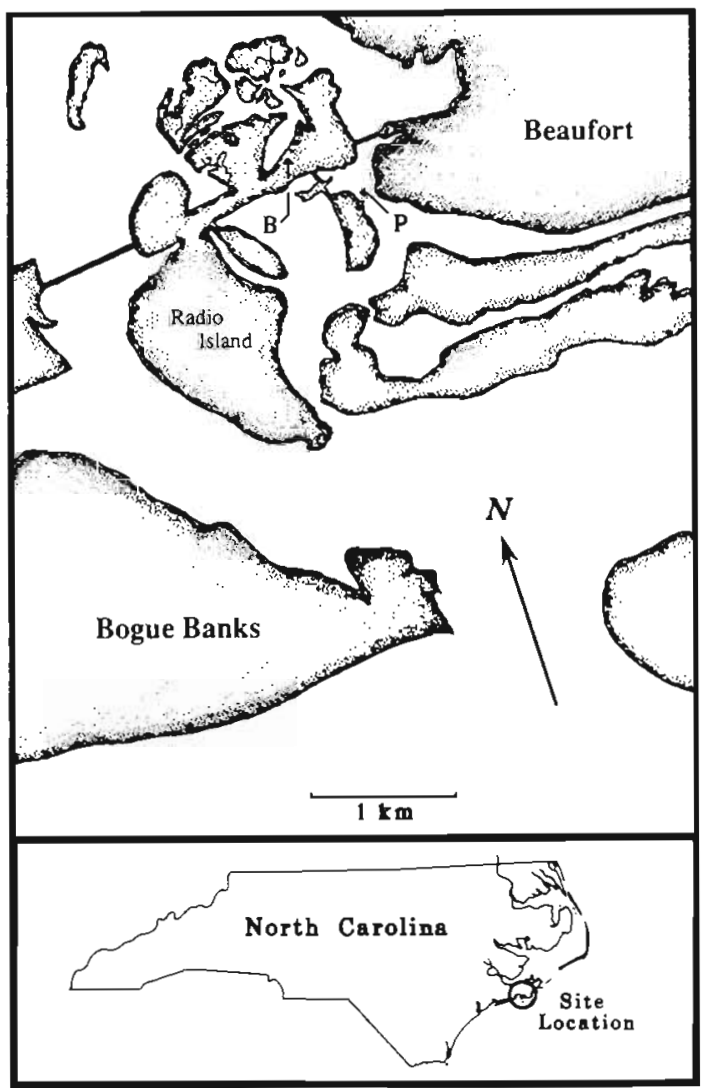

Fig. 1. Locations of benthic (B) and planktonic (P) sampling near Beaufort, North Carolina, USA. Shaded areas are coastal land masses

ments increased from 6.1 to $23.2 \%$, from the mudflat to higher elevations ( $O^{\prime}$ Connor unpubl. data).

Benthic sampling. Three $8 \mathrm{~m}$ wide contiguous transects were established along an intertidal gradient perpendicular to the shoreline from the mudflat of the tidal creek to within $10 \mathrm{~m}$ of the landward edge of the marsh (Fig. 2). Tall wooden stakes marked 4 intertidal habitat zones: mudflat, marsh edge, mid marsh and high marsh. The total change in intertidal elevation along a transect was about $0.5 \mathrm{~m}$.

To estimate adult crab densities, one $1 \mathrm{~m}^{2}$ permanent quadrat was established adjacent to the easternmost transect markers of each transect by placing short wooden stakes into the marsh surface. At low tide of each monthly sampling period I visually scanned each quadrat for adult crabs. The 2 species were distinguished by differences in color (Crane 1975. Montague 1980). Counts of adult crabs were recorded verbally into a tape recorder. Transects were sampled monthly from May to August 1987 and from May to July and again in September 1988.

Larval and juvenile fiddler crabs also were collected monthly from mudflat, marsh edge, mid marsh and high marsh locations on each transect. Collections were made by placing a square wooden frame $\left(0.16 \mathrm{~m}^{2}\right.$ total area) onto the marsh surface at low tide; clipping all marsh grass stalks near the surface of the marsh; scraping the surface $1 \mathrm{~cm}$ of mud, or to the below-ground root mass if surface mud was $<1 \mathrm{~cm}$ deep; and sieving each sample through a $0.5 \mathrm{~mm}$ mesh screen with tidal creek water. Samples then were sorted in the laboratory by spreading subsamples in a shallow white pan and removing all crabs. During each monthly sampling period I moved the location of sampling westward so that previously sampled surfaces would not be resampled within 1 season. Each transect was sampled during August and September 1986 (except the mudflat, which was not emersed during that sampling period), and May through September 1987. The mid and high marsh areas of each transect were sampled again in September 1988 to provide a 3 yr dataset of total juvenile crab abundance (both species combined) near the end of the settlement season. All benthic sampling for adults and juveniles was done on $2 \mathrm{~d}$ around the time of a spring tide.

Because young juvenile crabs could not be identified to species, they were reared in the laboratory until they reached 4 to $5 \mathrm{~mm}$ in carapace width. At that size Uca pugilator could be distinguished from $U$. pugnax by the presence of spoon-tipped setae on the meropodite of the second maxilliped ( $O^{\prime}$ Connor 1990a). Mortality of field-caught crabs (settlers and juveniles) during rearing was $\leq 15 \%$, and was most likely similar for both species, based on data from rearing larvae released from ovigers of both species through several juvenile instars (O'Connor 1990a).

Fig. 2. Diagram illustrating the arrangement of intertidal transects, and location of habitat zones within each transect

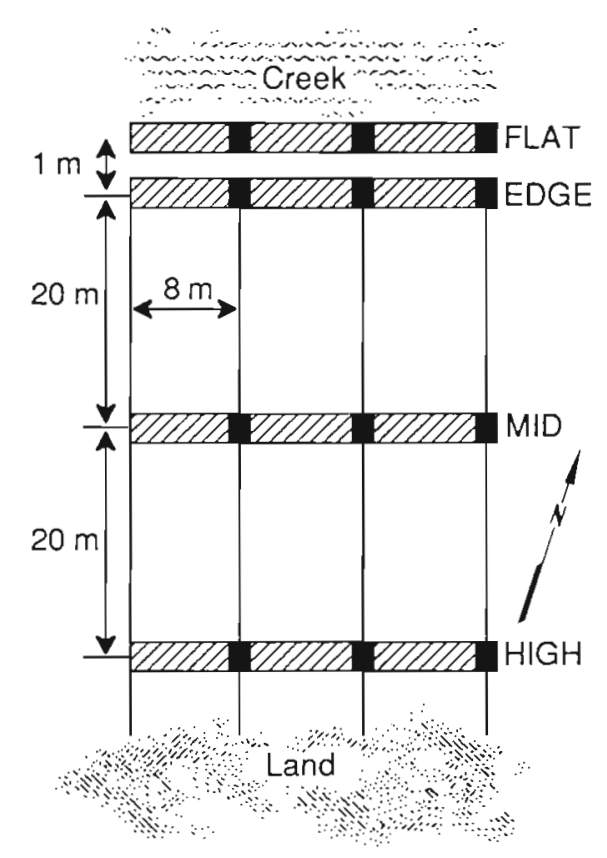


For each species, the proportion of juvenile and adult crabs that occurred on the marsh edge zone within each of the 3 replicate transects was calculated, ignoring the mudflat data because crabs were there only temporarily (see 'Results'). This particular calculation was chosen because of the skewed spatial pattern of Uca pugilator (see 'Results'), which precluded statistical comparisons at each habitat zone. Proportions were arcsin transformed before statistical analysis. Differences between species were tested with a 3-way ANOVA using species, transect, and date as the 3 main variables. Differences between 2 age classes (juveniles and adults) within species in 1987 were tested with a 4-way ANOVA with age class, species, transect and date as the main variables.

Plankton sampling. Spatial patterns of larval settlement are determined most accurately by sampling the benthos when larvae are actually settling from the water column (Luckenbach 1984, Woodin 1986). To determine whether the intertidal patterns of settlers found during the monthly benthic sampling were representative of patterns occurring during larval settlement, I documented larval availability by sampling the plankton daily for $71 \mathrm{~d}$ in the summer of 1988. Larvae were sampled using stationary filter collectors known to retain crab megalopae (van Montfrans et al. 1990) because of the tendency of larvae to cling to objects in the water column (Shanks 1985). Collectors consisted of $43 \times 32 \mathrm{~cm}$ pieces of air-conditioner filter weighted with galvanized pipe, and suspended from a rope connected to a pulley system on a piling ca $9 \mathrm{~m}$ from a National Marine Fisheries Service dock in a tidal channel (Fig. 1). Two collectors were suspended in a pair, one hanging from the surface to $43 \mathrm{~cm}$ depth, the other from $43 \mathrm{~cm}$ to $86 \mathrm{~cm}$ below the surface. The collectors remained in water that ranged from ca 1.5 to $2.5 \mathrm{~m}$ in depth over a tidal cycle. Collectors were placed in the water between 08:00 and 09:00 h and retrieved $24 \mathrm{~h}$ later. Animals present on each collector were removed by rinsing the collector with freshwater spray, then concentrating each sample on a $0.5 \mathrm{~mm}$ mesh sieve. The number of fiddler crab megalopae in each sample was determined immediately after collection by adding $95 \%$ ethanol to the sample and sorting it using a dissecting microscope. Fiddler crab megalopae were identified only to genus because the megalopae of the 3 species present in North Carolina salt marshes (UCa pugilator, $U$. pugnax, and $U$. minax) cannot be differentiated morphologically (Hyman 1920, Sandifer 1972). After a peak in abundance of planktonic larvae was observed, I again sampled the marsh surface for settled crabs using the methods described previously.

\section{RESULTS}

\section{Benthic sampling}

Adults of the 2 species of fiddler crab were distributed differently in the marsh. Adult Uca pugilator generally were present only on the marsh edge (Fig. 3). $U$. pugnax adults were present throughout the marsh, but tended to be more abundant at higher elevations (Fig. 3). Within each transect, a significantly greater proportion of $U$. pugilator than $U$. pugnax occurred on the marsh edge; the proportion of $U$. pugilator vs $U$. pugnax (mean $\pm 1 \mathrm{SD}$ ) was $0.75 \pm 0.38$ vs $0.16 \pm$ 0.17 in 1987 (ANOVA $p=0.004$ ), and $0.93 \pm 0.10$ vs $0.15 \pm 0.17$ in $1988(\mathrm{p}=0.029$ ). The only adult crabs ever seen on the mudflat were $U$. pugilator that were feeding there. These patterns of distribution and abundance of adults of the 2 species were consistent both within and between years (Fig. 3 ).
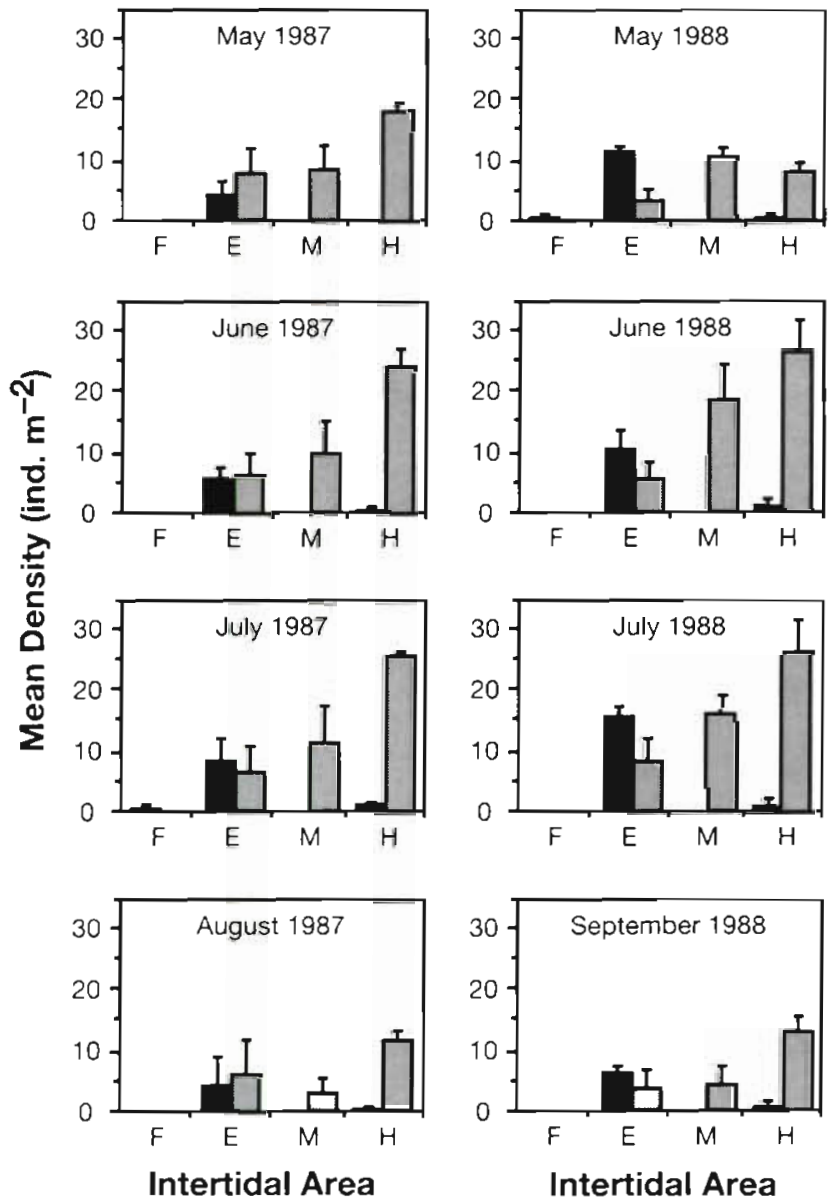

Fig. 3. Uca pugilator, U. pugnax. Mean densities (ind. $\mathrm{m}^{-2}$ ) of adult fiddler crabs in 4 intertidal areas of a salt marsh during different months and years. Solid bars $=U$. pugilator, stippled bars $=U$. pugnax. Error bars $=+1 \mathrm{SEM}, \mathrm{n}=3$. $\mathrm{F}$ : mudflat; E: marsh edge; $M$ : mid marsh; $H$ : high marsh 

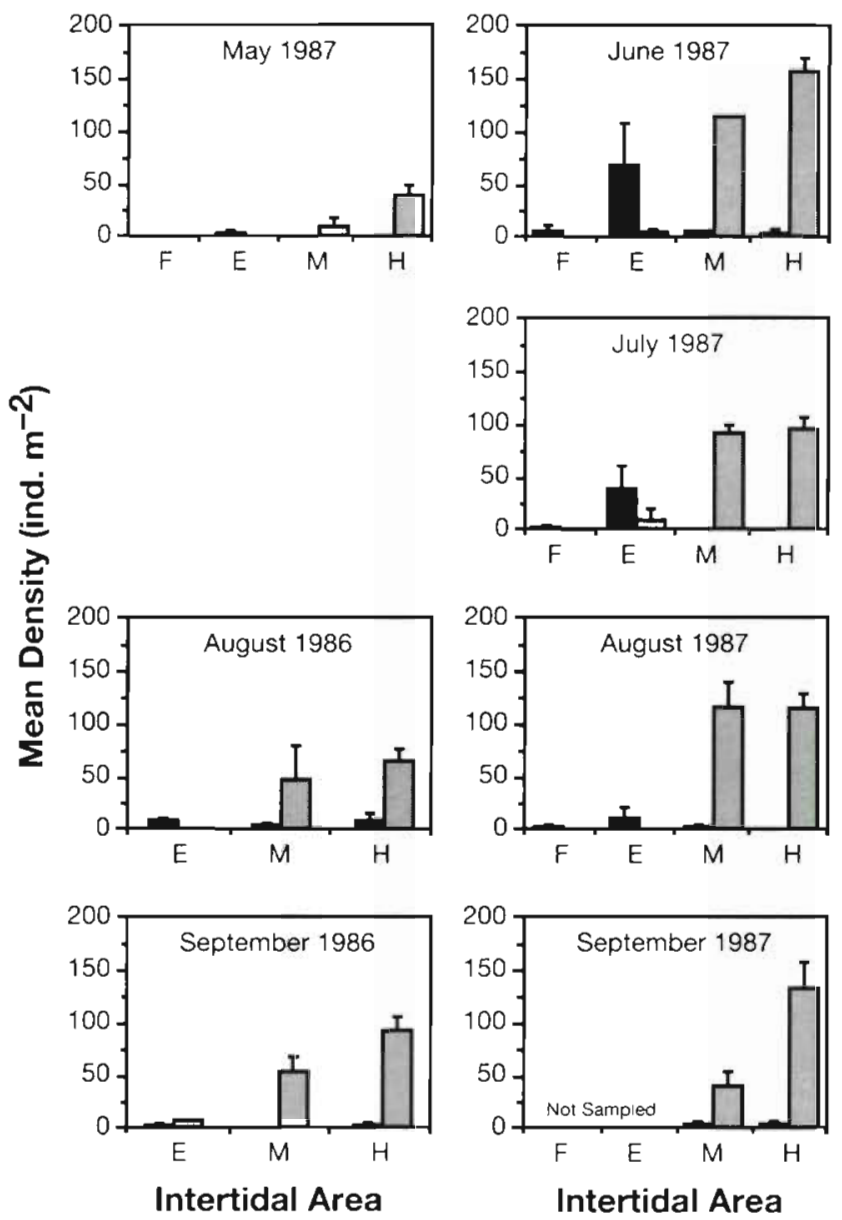

Fig. 4. Uca pugilator, U. pugnax. Mean densities (ind. $\mathrm{m}^{-2}$ ) of juvenile (crabs up to $5 \mathrm{~mm}$ carapace width) $U$. pugilator (solid bars) and $U$. pugnax (stippled bars) in 4 areas along an intertidal gradient of a salt marsh during different months and years. Error bars $=+1 \mathrm{SEM}, \mathrm{n}=3 . \mathrm{F}$ : mudflat; $\mathrm{E}$ : marsh edge; $\mathrm{M}$ : mid marsh; $\mathrm{H}$ : high marsh

Conspecific juvenile and adult crabs had similar distributions, although juveniles were more abundant. Juvenile Uca pugilator occurred mostly on the marsh edge, whereas juvenile $U$. pugnax were present mostly in mid and high marsh areas (Fig. 4). A significantly greater average proportion of juvenile $U$. pugilator $(0.70$ $\pm 0.48)$ than $U$. pugnax $(0.01 \pm 0.04)$ occurred on the marsh edge in 1987 (ANOVA $p=0.033$ ), but not in 1986 $(0.50 \pm 0.50$ vs $0.03 \pm 0.03, p=0.49)$, possibly because of the low abundances of juvenile $U$. pugilator in the 1986 samples (Fig. 4). For both species, there was no significant difference in the proportion of juvenile and adult crabs present on the marsh edge in 1987 (ANOVA Age class $p=0.32$, Age class $\times$ species $p=0.34$ ).

The total abundances of juvenile crabs (both species combined) in the mid and high marsh areas did not differ among the 3 years (ANOVA $p=0.18$ ), and more juveniles occurred in the high than the mid marsh zone $(p=0.011)$. In September 1988 the mean density ( \pm 1 SEM) of juvenile crabs (both species combined) in the mid marsh area was $100.0( \pm 34.8) \mathrm{crabs}^{-2}$, and in the high marsh it was $172.9( \pm 65.0) \mathrm{crabs} \mathrm{m}^{-2}$. These abundance patterns are comparable to results observed in 1986 and 1987 (Fig. 4), even though abundances were somewhat greater in 1988 .

Although too few settlers were found to be included in the statistical analysis, the distribution and abundance patterns of those settlers collected during 7 mo of sampling the marsh benthos in 1986 and 1987 and reared in the laboratory corresponded to those of conspecific juvenile and adult crabs. More Uca pugnax were found in the mid and high marsh samples, whereas more U. pugilator occurred on the marsh edge (Fig. 5). No settlers were found on the unvegetated mudflat, only $1 \mathrm{~m}$ from the vegetated marsh surface.

\section{Plankton sampling}

Abundance of $U$ ca spp. meglaopae in the plankton was low in early June 1988, peaked in mid June, then remained at relatively low levels through mid August, when the collection period ended (Fig. 6). The number of fiddler crab megalopae collected at the 2 depths over $24 \mathrm{~h}$ periods appeared similar. I sampled the marsh surface near the beginning of the peak (13 June) and again near the end of the peak (17 June), and found more settlers on the marsh surface after the peak than before it (Fig. 7) (2-way ANOVA on the difference in number of settlers in each area of each transect, before and after the peak, $p=0.001$ ). Further, $29 \%$ of

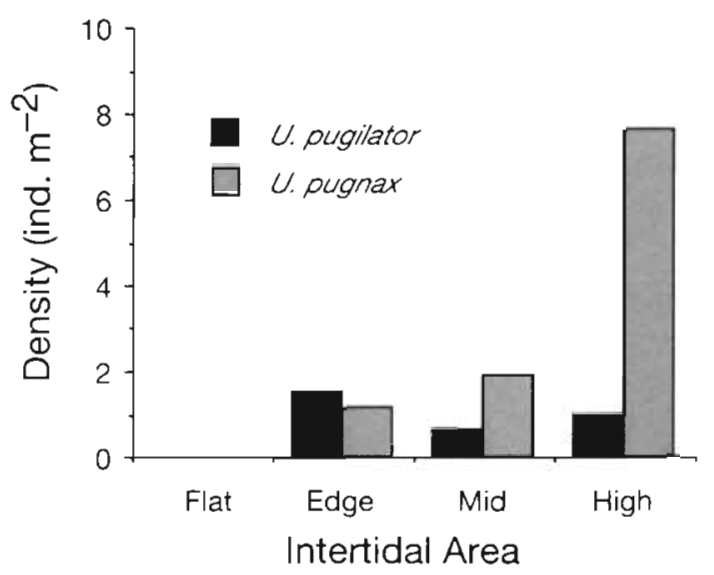

Fig. 5. Uca pugilator, U. pugnax. Density of all fiddler crab settlers (megalopae + stage I crabs) collected during 7 mo of benthic sampling in 1986 and 1987 and reared in the laboratory for determination of species. The total number of individuals of each species found and the total area of the marsh surface sampled within each habitat zone were summed to yield the values for density 


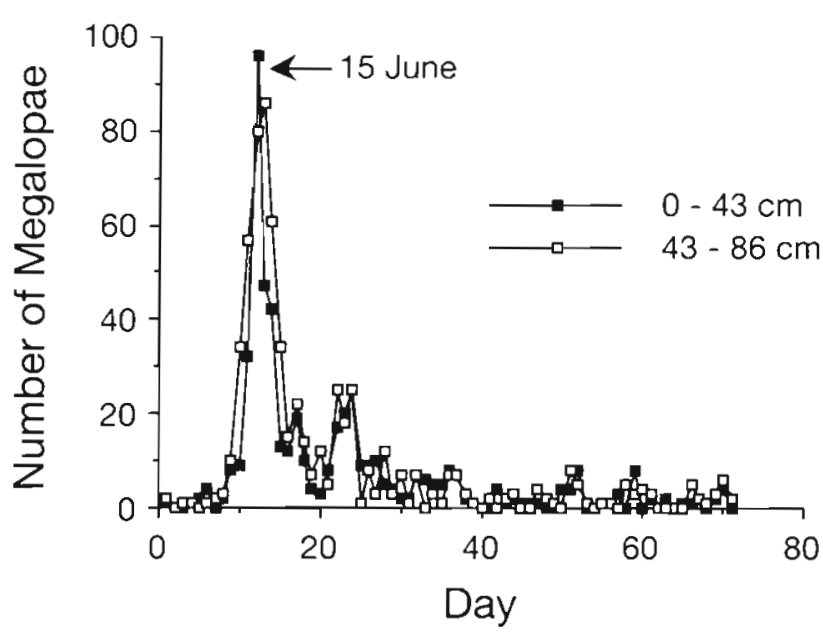

Fig. 6. Uca spp. Planktonic abundance of megalopae present on 2 collectors suspended at different depths in a tidal channel (see Fig. 1) and sampled daily in June, July and part of August 1988; note settlement peak on 15 June

the settlers on 17 June were still in the megalopal stage, whereas almost all of the settlers found in all previous samples had molted to the first crab instar. Thus, an increase in larval abundance in the water column was followed by an increase in settlement, even though the number of settlers on the marsh was not large. No settlers were found on the mudflat (Fig. 7). To determine whether substantial settlement occurred when few Uca spp. megalopae were collected from the plankton, I periodically scanned the marsh surface for recently-settled crabs. No pulse of larval settlement similar to that seen after the megalopal peak occurred, although larvae continued to settle in relatively low numbers throughout the summer.

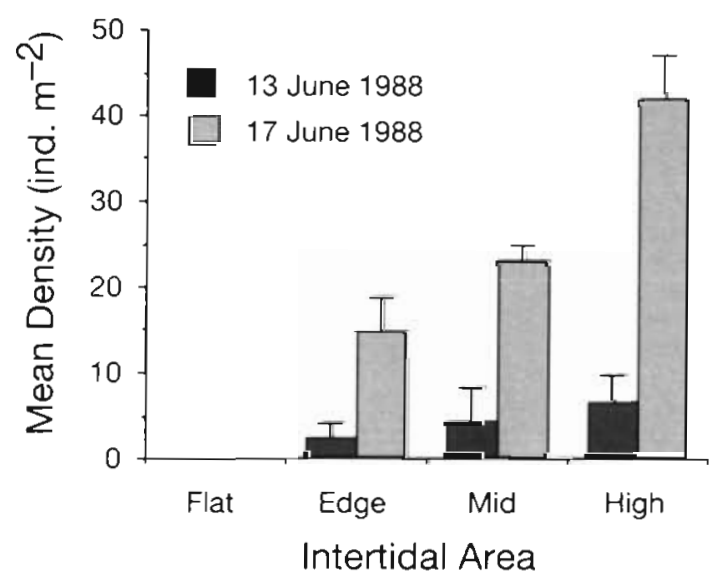

Fig. 7 Uca pugilator, U. pugnax. Mean densities of settling fiddler crabs (no. of megalopae + stage $I$ crabs $\mathrm{m}^{-2}$ ) along an intertidal gradient before (13 June) and after ( $17 \mathrm{June}$ ) a peak of Uca spp. megalopae in the plankton. Error bars $=+1 \mathrm{SEM}$, $\mathrm{n}=3$
Mortality of settlers during laboratory rearing was greater for crabs collected after the planktonic megalopal peak $(71 \%)$ than for settlers collected previously $(20 \%)$. Therefore, intertidal location of settlement for each species could not be determined accurately from this single settlement event. However, species distributions of surviving settlers were similar to those of settlers found previously: all 7 survivors from the mid and high marsh areas were Uca pugnax, and 3 of 4 of the survivors from the marsh edge were $U$. pugilator. Comparison of the distributions of all settlers of each species found throughout this study shows that $62 \%$ (8/13) of all $U$. pugilator settlers collected were present on the marsh edge, whereas only $10 \%(4 / 41)$ of $U$. pugnax settlers occurred there (mortality for all settlers combined $=43 \%$ ).

\section{DISCUSSION}

For both Uca pugnax and $U$. pugilator, the distribution and abundance patterns of settling, juvenile and adult fiddler crabs were very similar. Megalopae settled in intertidal areas occupied by older conspecifics, and the vertical distribution and abundance patterns present at settlement were maintained throughout the rest of benthic life. Although fiddler crabs are motile and can leave habitats after settlement, their movement appears to be restricted to the general intertidal location of settlement and metamorphosis.

Megalopae of the 2 species settled in different areas of the marsh. Hence larvae may have specific habitat preferences during settlement that are important in determining the distribution and abundance patterns of all subsequent benthic stages. The vertical swimming behavior of the megalopae may facilitate their transport from nearshore larval nursery areas to estuarine adult habitats. The occurrence of megalopae in surface waters during flooding tides and in bottom waters during ebbing tides (Christy 1982, Meredith 1982, Epifanio et al. 1988, Little \& Epifanio 1991) results in a net landward movement of the larvae. If larvae contact the substratum they could detect physical and chemical stimuli present, and choose to swim upward again or remain in place until metamorphosis occurs. Fiddler crab megalopae can advance molting to the first crab instar in the presence of sediments with chemical stimuli from older conspecifics. and delay molting in their absence (Christy 1989 , O'Connor 1991).

In a study of a population of UCa pugnax in Massachusetts, USA, Krebs \& Valiela (1978) found that juvenile crabs $(<5 \mathrm{~mm}$ carapace width) exhibited distribution and abundance patterns similar to those of adults, although abundance of both size classes 
was greatest near a tidal creek and decreased at higher intertidal elevations. In the present study, $U$. pugnax occurred throughout the marsh with increasing abundance landward, whereas all 3 size classes of $U$. pugilator occurred mostly on the marsh edge (Figs. $3,4 \& 5$ ). Although $U$. pugnax in the 2 studies had dissimilar intertidal distributions, perhaps explainable by differences in marsh topography or sediment characteristics, in both studies the abundance of juvenile crabs was correlated with that of conspecific adults.

Some $U_{C a}$ pugilator settled in the mid marsh area, whereas few juvenile and no adult $U$. pugilator occurred there (Figs. 3, 4 \& 5). Because the proportion of $U$. pugilator in the mid marsh decreased with age/size of the crabs, it is possible that post-settlement movement or mortality contributed to the spatial pattern seen for adults. Postsettlement mortality is suspected because Teal (1958) found that, compared to U. pugnax, U. pugilator survived poorly when caged in a muddy low marsh area.

The densities of settlers were always much lower than those of juveniles at all intertidal areas in the marsh. At least 2 explanations could account for this trend. First, the term 'settlers' represented megalopae and the first crab instar only, whereas the category 'juveniles' comprised all crabs from the second to about the seventh instar, based on observations of lab-reared individuals (O'Connor 1990a). Consequently, crabs that settled in the marsh would have spent much more time in the juvenile than the settler category ( $\geq 1 \mathrm{mo}$ vs $<2 \mathrm{wk}$ ). Second, megalopae that settle on the marsh may have a relatively high probability of surviving. Predation of $U c a$ spp. megalopae by fishes in tidal creeks can be quite high (Johnson et al. 1990), and may represent a more significant source of mortality than predation of newlysettled crabs in the vegetated marsh.

For the relatively few species of motile marine invertebrates that have been studied, the relationship between the distributions of settlers and adults varies. Larvae of the sea hare Aplysia juliana (Sarver 1979) and the snail Littorina neritoides (Fretter \& Manly 1977) settle in locations separate from the adult habitat, then move to it after a period of feeding and growth. Porcelain and fiddler crab megalopae appear to settle gregariously in adult habitats (Jensen 1989, this study). Young juvenile stages of the crabs Carcinus maenas (Klein Breteler 1976) and Callinectes sapidus (Orth \& van Montfrans 1987) and the lobsters Panulirus argus (Marx \& Herrnkind 1985, Herrnkind \& Butler 1986) and Homarus americanus (Hudon 1987. Wahle \& Steneck 1991, 1992) occur in specific, spatially restricted microhabitats within the adult habitat where food is abundant and predation is reduced; they expand their habitat range at later stages. Constraints imposed by both the capacity for post-settlement movement and the availability of food and shelter within the adult habitat are probably important in determining whether larvae settle in the adult habitat and the habitat range of juveniles.

In summary, this study indicates that the distribution of newly-settled and adult fiddler crabs are correlated because megalopae settle preferentially in intertidal habitats occupied by conspecific adults. The extent of horizontal movement of juveniles within the adult habitat, and the influence of other processes on juvenile recruitment remain poorly known.

Acknowledgements. I am grateful to several people who helped with obtaining or sorting benthic samples at various times during the course of this study: B. Thomas, D. Wolcott, L. Nye, G. and G. Maillet, S. Clark and especially S. Dobihal. I thank G. Thayer and the staff of the National Marine Fisheries Service, Beaufort, NC, for the use of their facilities, and J. van Montfrans and R. Orth (Virginia Institute of Marine Science) for information on designing the plankton collection system. C. Brownie assisted me greatly with the statistical analyses. I thank T. Wolcott, D. Wolcott, L. Levin, L. Crowder, G. Thayer, and D. Knott for valuable reviews of the manuscript. This study was partially supported by a grant from the Lerner-Gray Fund for Marine Research of the American Museum of Natural History, a Grant-in-Aid of Research from Sigma $\mathrm{Xi}$, and funds from the Dept of Marine, Earth and Atmospheric Sciences, North Carolina State University. This study is part of a dissertation submitted in partial fulfillment of requirements for the Ph.D. degree at North Carolina State University

\section{LITERATURE CITED}

Branch, G. M. (1984). Competition between marine organisms: ecological and evolutionary implications. Oceanogr. mar. Biol. A. Rev. 22: 429-593

Christy, J. H. (1982). Adaptive significance of semilunar cycles of larval release in fiddler crabs (genus $U c a$ ): test of an hypothesis. Biol. Bull. 163: 251-263

Christy, J. H. (1989). Rapid development of megalopae of the fiddler crab $U_{\text {Ca }}$ pugilator reared over sediment: implications for models of larval recruitment. Mar. Ecol. Prog. Ser. 57: $259-265$

Christy, J. H., Stancyk, S. E. (1982). Timing of larval production and flux of invertebrate larvae in a well-mixed estuary. In: Kennedy, V. S. (ed.) Estuarine comparisons. Academic Press, New York, p. 489-503

Colby, D. R., Fonseca, M. S. (1984). Population dynamics, spatial dispersion and somatic growth of the sand fiddler crab Uca pugilator. Mar. Ecol. Prog. Ser. 16: 269-279

Crane, J. (1975). Fiddler crabs of the world. Princeton University Press, Princeton

Crisp, D. J. (1984). Overview of research on marine invertebrate larvae, 1940-1980. In: Costlow, J. D., Tipper, R. C. (eds.) Marine biodeterioration: an interdisciplinary study. Naval Institute Press, Annapolis, MD, p. 103-126

Epifanio, C. E., Little, K. T., Rowe, P. M. (1988). Dispersal and recruitment of fiddler crab larvae in the Delaware River estuary. Mar. Ecol. Prog. Ser. 43: 181-188

Fretter, V., Manly, R. (1977). The settlement and early benthic life of Littorina neritoides (L.) at Wembury, S. Devon. J. molluscan Stud. 43: 255-262 
Full, R. J., Herreid, C. F. II (1984). Fiddler crab exercise: the energetic cost of running sideways. J. exp. Biol. 109 . $141-161$

Hadfield, M. G. (1986). Settlement and recruitment of marine invertebrates: a perspective and some proposals. Bull. mar. Sci. 39: 418-425

Herrnkind, W. F. (1968). The breeding of Uca pugilator (Bosc) and mass rearing of the larvae with comments on the behavior of the larval and early crab stages (Brachyura, Ocypodidae). Crustaceana suppl. (Leiden) 2: 214-224

Herrnkind, W. F., Butler, M. J. IV (1986). Factors regulating postlarval settlement and juvenile microhabitat use by spiny lobsters Panulirus argus. Mar. Ecol. Prog. Ser. 34: $23-30$

Hettler, W. F. Jr (1989). Nekton use of regularly-flooded saltmarsh cordgrass habitat in North Carolina, USA. Mar Ecol. Prog. Ser. 56: 111-118

Hudon, C. (1987). Ecology and growth of postlarval and juvenile lobster, Homarus americanus, off Iles de la Madeleine (Quebec). Can J. Fish. Aquat. Sci. 44: 1855-1869

Hyman, O. W. (1920). The development of Gelasimus after hatching. J. Morphol. 33: 485-525

Jensen, G. C. (1989). Gregarious settlement by megalopae of the porcelain crabs Petrolisthes cinctipes (Randall) and $P$. eriomerus Stimpson. J. exp. mar. Biol. Ecol. 131: $223-231$

Johnson, W. S., Allen, D. M., Ogburn, M. V., Stancyk, S. E. (1990). Short-term predation responses of adult bay anchovies Anchoa mitchilli to estuarine zooplankton availability. Mar. Ecol. Prog. Ser. 64: 55-68

Keough, M. J., Downes B. J. (1982). Recruitment of marine invertebrates: the role of active larval choices and early mortality. Oecologia 54: 348-352

Klein Breteler, W. C. M. (1976). Settlement, growth and production of the shore crab, Carcinus maenas, on tidal flats in the Dutch Wadden Sea. Neth. J. Sea Res, 10:354--376

Kneib, R. T., Stiven, A. E. (1978). Growth, reproduction, and feeding of Fundulus heteroclitus (L.) on a North Carolina salt marsh. J. exp. mar. Biol, Ecol. 31, 121-140

Krebs, C. T., Valiela, I. (1978). Effect of experimentally applied chlorinated hydrocarbons on the biomass of the fiddler crab, Uca pugnax (Smith). Estuar. coast. mar. Sci. 6: 375-386

Lambert, R., Epifanio, C. E. (1982). A comparison of dispersal strategies in two genera of brachyuran crab in a secondary estuary. Estuaries 5: 182-188

Levinton, J. S. (1982). Marine ecology. Prentice-Hall, Englewood Cliffs

Little, K. T., Epifanio, C. E. (1991). Mechanism for the reinvasion of an estuary by two species of brachyuran megalopae. Mar. Ecol. Prog. Ser. 68: 235-242

Luckenbach, M. W. (1984). Settlement and early post-settlement survival in the recruitment of Mulinia lateralis (Bivalvia). Mar. Ecol. Prog. Ser. 17: 245-250

Marx, J. M., Hernkind, W. F. (1985). Macroalgae (Rhodophyta: Laurencia spp.) as habitat for young juvenile spiny lobsters, Panulirus argus. Bull. mar. Sci. 36: 423-431

This article was submitted to the editor
Meredith, W. H. (1982). The dynamics of zooplankton and micronekton community structure across a salt marshestuarine waters interface of lower Delaware Bay. Ph.D. dissertation, University of Delaware, Newark

Montague, C. L. (1980). A natural history of temperate western Atlantic fiddler crabs (genus Uca) with reference to their impact on the salt marsh. Contrib. mar. Sci. 23: $25-55$

O'Connor, N. J. (1990a). Morphological differentiation and molting of juvenile fiddler crabs (Uca pugilator and U. pugnax). J. crustac. Biol. 10: 608-612

O'Connor, N. J. (1990b). Larval settlement and juvenile recruitment in fiddler crab populations. Ph.D. dissertation, North Carolina State University, Raleigh

O'Connor, N. J. (1991). Flexibility in timing of the metamorphic molt by fiddler crab megalopae Uca pugilator. Mar. Ecol. Prog. Ser. 68: 243-247

Orth, R. J, van Montfrans, J. (1987). Utilization of a seagrass meadow and tidal marsh creek by blue crabs Callinectes sapidus. I. Seasonal and annual variations in abundance with emphasis on post-settlement juveniles. Mar. Ecol. Prog. Ser. 41:283-294

Reaka, M. L. (1987). Adult-juvenile interactions in benthic reef crustaceans. Bull. mar. Sci. 41: 108-134

Sandifer, P. A. (1972). Morphology and ecology of Chesapeake Bay decapod crustacean larvae. Ph.D. dissertation, University of Virginia, Charlottesville

Sarver, D. J. (1979). Recruitment and juvenile survival in the sea hare Aplysia juliana (Gastropoda: Opisthobranchia). Mar. Biol. 54: 353-361

Shanks, A. L. (1985). Behavioral basis of internal-waveinduced shoreward transport of megalopae of the crab Pachygrapsus crassipes. Mar. Ecol. Prog. Ser. 24: 289-295

Stiven, A. E., Kuenzler, E. J. (1979). The response of two salt marsh molluscs, Littorina irrorata and Geukensia demissa, to field manipulations of density and Spartina litter. Ecol. Monogr. 49: 151-171

Teal, J. M. (1958). Distribution of fiddler crabs in Georgia salt marshes. Ecology 39: 185-193

van Montfrans, J., Peery, C. A., Orth, R. J. (1990). Daily, monthly and annual settlement patterns by Callinectes sapidus and Neopanope sayi megalopae on artificial collectors deployed in the York River, Virginia: 1985-1988. Bull. mar. Sci. 46: 214-229

Wahle, R. A., Steneck, R. S. (1991). Recruitment habitats and nursery grounds of the American lobster Homarus americanus: a demographic bottleneck? Mar. Ecol. Prog. Ser. 69: $231-243$

Wahle, R. A., Steneck, R. S. (1992). Habitat restrictions in early benthic life: experiments on habitat selection and in situ predation with the American lobster. J. exp. mar. Biol. Ecol. 157: 91-114

Werner, E. E., Gilliam, J. F. (1984). The ontogenetic niche and species interactions in size-structured populations. A. Rev. Ecol. Syst. 15: 393-425

Woodin. S. A. (1986). Settlement of infauna: larval choice? Bull. mar. Sci. 39: 401-407

Manuscript first received: December 30,1991

Revised version accepted: January 8, 1993 